\title{
A STUDY OF THE RELATIONSHIP BETWEEN SERVICE QUALITY AND VISITORS SATISFACTION IN UPPER EGYPT MUSEUMS
}

\section{AHMED EBIED \\ FACULTY OF TOURISM AND HOTELS, LUXOR UNIVERSITY, EGYPT}

\begin{abstract}
The importance of visitors and guests can be overstated. To stay competitive, museums must continue to please their visitors in order to increase profitability and market share. They need to figure out what their consumers require, want, and value. This research paper's aim is to assess the visitors' views related to tourism services quality in Upper Egypt museums. It attempts to measure the extent to which the tourism business environment is creative and innovative as necessary conditions for guests' satisfaction. Throughout the previous few decades, many research projects have focused on service quality. It was discovered in recent decades that the quality of services has a major impact on satisfaction.

The purpose of this research is to investigate the visitors in their satisfaction for service and facilities regarding five service quality dimensions: tangibles, reliability, responsiveness, assurance and empathy in Upper Egypt museums. Results have revealed that there is a positive and significant relationship between the five dimensions of SERVQUAL and the level of satisfaction for the museums' visitors.
\end{abstract}

KeYWORDS: Tourism, Servqual, Upper Egypt Museums, Tourist Satisfaction.

\section{INTRODUCTION}

Quality and Tourism are a package deal especially after the strong competition happening as a result of new information technologies, deregulations and globalization (Titu et al. 2016). He added that service quality has become a serious issue in the tourism sector as it is considered a crucial aspect in creating tourists' satisfaction and delights. Pakurar (2019) stated that service quality is the key to success as it affects customers' judging and satisfaction. It also plays an important role in loyalty behavior as positive outcomes resulted from loyal and satisfied customers in recommending and revisiting intentions (Barshan et al., 2017). 
Museums are considered one of the cultural and historical resources in any destination that attract tourists as they play an important role in linking the past with the present in addition to their role in preserving the cultural heritage (Duantrakoonsil, 2017).

This research aims to investigate the visitors of Upper Egypt museums in their satisfaction for services and facilities regarding the five service quality dimensions of the SERVQUAL which are: tangibility, reliability, responsiveness, assurance and empathy. Therefore, assessing service quality offered by these museums is very essential in providing better service to visitors and thus strengthening visitor experiences as they are considered a part of Cultural tourism.

\section{LITERATURE REVIEW}

\section{SERVICE QUALITY}

Researchers gathered that service quality is hard to be judge and define as it is the efficient manner of the service provider through which satisfying customer, thus their opinion towards the service is considered the best measurement for it (Ramya et al., 2019). According to El Saghier (2015), the main person who can define the service quality is the customer. This word is always associated with meeting or exceeding customer needs and expectations and also the degree of suitability of products and services to conditions (Goetsch \& Davis, 2014). According to Seetue (2009), evaluating service is more challenging than goods. Ramya et al. (2019), Gebremichael and Singh (2019) clarified that the intangibility and inseparability of the service make it hard to be checked like goods and the only way in assessing the quality of the service is to compare the expected service quality with the perceived one. Thus, service quality is considered one of the important tools in nowadays' competition conditions especially for organizations or businesses that seek profitability continuity, surviving in the market and success; so, they have to seek for meeting customers' needs and expectations more effectively and efficiently (Unuvar and Yapici, 2016).

Parasuraman et al. (1985) and Panasuraman et al. (1988) reported five dimensions that have to be evaluated by comparing these expectations of the customer to the perceptions of the performed service in a model called the SERVQUAL model and this model is the most widely and accepted one in measuring the quality of the service.

\section{MUSEUMS SERVICE QUALITY}

Museums are considered one of the main attraction and important organizations of culture and heritage as they offer education, leisure in 
addition to entertainment (Mey and Mohamed, 2010). Therefore, they have to focus on satisfying visitors to be able to create repeating visits (Castellani et al., 2019). According to Mey and Mohamed (2010), museums are considered one of the important products of tourism and places where touristic services take place.

Nowadays, sustainable development in tourism field is related to heritage and culture resources, so protecting them in addition to the region's environment will participate greatly in maintaining quality of social, cultural, physical and environmental resources of the tourism destination during its competition in the market (Markovic et al., 2013). Markovic et al. (2013)

Daskalaki (2020) stated that museums service quality is somehow a complex concept as it refers to various aspects related to the museum experience as it relates to the exhibits and how they are presented in addition to the empathy and competence of the personnel working. Preko et al. (2020) clarified that satisfaction begins from the first moment of seeking a car park till the last moment of leaving the museum.

Thus, satisfied customers got revisit intentions that obtained from their satisfaction and perceiving high levels of value that direct them positively to repeat their visits and be more likely to recommend such place (Omar et al., 2016).

\section{DIMENSIONS OF MUSEUM SERVICE QUALITY}

Measuring the service quality in museums was reviewed by several authors by listing the basic elements of museums' service quality. Frochot and Hughes (2000) proposed a five-dimension model called HISTOQUAL. These five dimensions comprise: tangibles including (internal and external environment, attractiveness, cleanliness and authenticity), responsiveness, communication, empathy and consumables such as additional services like bazars and restaurants.

Rentschler and Gilmore (2002) suggested that accessibility, communication, education, frequency and relevance of special exhibits are the most important factors that deliver museums' service quality.

Phaswana- Mafuya and Haydam (2005) revealed that museums' service quality consists of: cleanliness, accessibility, safety in addition to providing information. Nowacki (2005) used the SERVQUAL evaluation method for assessing the quality of the National Museum which is located in Poznan at the Western of Poland. 
Hui-Ying and Chao-Chien (2008) indicated that a structure of five elements affects museums' service quality which is tangibility, reliability, responsiveness and assurance, educational entertainment and convenience. Mey and Mohamed (2010) revealed that accessibility, quality of the exhibits, information sources, facilities and amenities, customer services and souvenirs, and food and beverage pricing the main factors that affect service quality in museums. Radder and Han (2011) reported that the quality of museums' services, products and visiting experience are the main influencing aspects in such measurement.

Finally, Markovic and Jankovic (2019) referred to five main dimensions labeled as tangibles, accessibility, empathy, communication, and exhibition presentation for measuring the perceived museums' service quality.

\section{SERVQUAL MODEL}

It is a diagnostic tool that measure the quality level of the service as it compares the perception that comes from receiving the service with the customers' expectations towards it, thus helping the service providers in identifying their strengths and weaknesses towards the service and seeking to meet customers' expectations to reach their satisfaction and delight (Bhat, 2012).

\section{DIMENSIONS OF SERVQUAL MODEL}

El- Saghier (2015) stated that SERVQUAL model has five dimensions which are proposed as: tangibility, reliability, responsiveness, assurance and empathy. Tangibles are all the visual appealing which includes the aspects and physical facilities, the appearance of the personnel working, all the equipment and tools present in the place and used in providing the service (Pwelle, 2014).

Reliability is the dimension which is related to performing the promised service dependently, consistently and accurately from the first time (Kabir and Carlsson, 2010). According to Ali et al. (2019), responsiveness is the factor that concerns the employees who provide the service and their willingness to help customers with prompt and quick service, answering their questions, paying attention to their requests and also offering a good complaint handling service. Assurance is how knowledgeable and courteous the service providers and staff are, safety, security and also the creditability to create confidence and trust to customers (KS and Thomas, 2015). Empathy is the degree of providing and treating customers as an individual, understanding their needs and providing an individualized attention for each (Qadri, 2015). 


\section{UPPER EGYPT MUSEUMS}

In Egypt, museums have typically been made as storages for artifacts (Hawass, 2005). Upper Egypt has several museums; from which:

The Sohag National Museum, this museum has a view on the Nile. It contains a multitude of items that demonstrate ancient Egyptian, Coptic, and Islamic religious ideas, in addition to some items that were relocated from the Egyptian Museum in Cairo, Gayer-Anderson, and the Coptic Islamic Art Museum, to present the history of Sohag governorate. This is in addition to discussing the governorate's heritage, family rituals and traditions, and spotlighting some of the governorate's most well-known businesses, such as textiles. It's worth noting that the project for the Sohag National Museum was first proposed in 1993, but it was stopped due to engineering and technical problems.

Luxor Museum is a Luxor archaeological museum (ancient Thebes). It is situated on the River Nile. It first opened its doors in 1975. It is a two-story structure for numerous ancient masterpieces and the glory of Thebes. The Luxor Museum presently features a museum library, a restaurant, and a new bookstore, as well as areas for children's education, in addition to the exhibition halls (El Mallah, 2018; Hawass, 2010).

The Mummification Museum is located to the north of Luxor temple on the Nile. It is one of Egypt's most important specialist museums, being opened in 1997 AD. This Museum exhibits the ancient Egyptian art of mummification as well as related artifacts and mummies. One can learn, what is the processes of mummification used to embalm a variety of animals, including crocodiles, cats, and fish, in this section. The museum has a lecture hall, video room, and cafeteria which are different sections present by the museum (Ministry of Tourism and Antiques, 2021).

The Nubia Museum which is located in Aswan is opened to the public in November 1997. It contains masterpieces discovered during excavations for UNESCO's International Campaign to save the monuments of Nubia, which were threatened by the Aswan High Dam building in the 1960s. The Museum is a focal point for Nubian history and culture, with collections from prehistory to the current day, as well as many of the approximately 3,000 masterpieces uncovered during the excavations (Elcheikh, 2014; Paolini, 2005).

\section{METHODOLOGY}

Questionnaires were distributed among random sample of the museums' visitors. They are used as a tool for data collection to measure the 
dimensions affecting visitors' satisfaction of Upper Egypt museums. The questionnaire was divided into three parts. First part is related to personal data which includes gender, age and the name of the museum. Second part is related to assessing the quality level of service provided by Upper Egypt museums and this part includes Likert scale with its associated values from (1 strongly disagree to 5 strongly agree). This scale is used to determine the significant differences and also to indicate the level of agreement and disagreement for the statements \& visitors' satisfaction towards the service provided at Upper Egypt museums. This in turn will reflect their overall satisfaction and recommendations to such museums. It also includes another Likert scale with values from (1 Not exist to 5 Perfectly exist) to determine the existence of things present in all museums like cafes and bazars. Third part is related to assessing the museums' visit and determines the satisfaction level using values from (1 unsatisfied at all to 5 totally satisfied). The mean used in determining the response to the study dimensions is Likert scales which is illustrated as follows as shown in the table (1)

Table (1): the 5 Point - Likert Scale

\begin{tabular}{|c|c|c||c|c|c|}
\hline \multirow{3}{*}{ Category } & $\begin{array}{c}\text { Strongly } \\
\text { Disagree }\end{array}$ & Disagree & Neutral & Agree & $\begin{array}{c}\text { Strongly } \\
\text { Agree }\end{array}$ \\
\cline { 2 - 6 } & Not exist & $\begin{array}{c}\text { Weakly } \\
\text { exist }\end{array}$ & $\begin{array}{c}\text { Moderately } \\
\text { exist }\end{array}$ & Exist & $\begin{array}{c}\text { Perfectly } \\
\text { exist }\end{array}$ \\
\cline { 2 - 6 } & $\begin{array}{c}\text { Unsatisfied } \\
\text { at all }\end{array}$ & Unsatisfied & Neutral & Satisfied & $\begin{array}{c}\text { Totally } \\
\text { satisfied }\end{array}$ \\
\hline \hline Scale & 1 & 2 & 3 & 4 & 5 \\
\hline \hline Rang & $\mathbf{1 - 1 . 8 0}$ & $\mathbf{1 . 8 1 - 2 . 6 0}$ & $\mathbf{2 . 6 1 - 3 . 4 0}$ & $\mathbf{3 . 4 1 -}$ & $\mathbf{4 . 2 1} \mathbf{- 5}$ \\
\hline
\end{tabular}

$* \operatorname{Rang}=(5-1 / 5)=0.80$

\section{SAMPLING}

The objective of this research is to investigate the visitors in their satisfaction for services and facilities regarding five service quality dimensions. Thus, questionnaires were uploaded on Google drive and they have been distributed through social media. Moreover, sharing the link and sending it through emails and whatsapp to friends and relatives who have visited Upper Egypt museums. They were (500) responses conducted from May to June 2021 distributed randomly among visitors.

\section{DATA ANALYSIS}

The statistical tool exploited in this research is the quantitative method 
analyzed by SPSS program version 25. Cronbach's Alpha is used to assess the reliability of the questions. Pearson Correlation is used to determine the correlation between research dimensions and tourists' satisfaction. Regression equations were also applied to know the dimensions that influence tourists' satisfaction.

\section{RESULTS AND DISCUSSION}

FIRST: RELIABILITY ANALYSIS

Table (2) Measuring reliability degree for the questionnaires

\begin{tabular}{|c|c|}
\hline Questions & Alpha Cronbach's \\
\hline \hline 42 & 0.966 \\
\hline
\end{tabular}

The reliability of the questionnaire was calculated by using the Cronbach's alpha coefficient. Taber, K. (2018) stated that the Cronbach's alpha is a statistical test commonly used to prove that the scales created to measure study variables are reliable and appropriate to their purpose. The results concluded that the Cronbach's alpha coefficient for all variables was higher than 0.7, as shown in table (2). Thus, he mentioned that the Cronbach's alpha coefficient is acceptable if its value is 0.7 and higher.

SECOND: DESCRIPTIVE ANALYSIS

Table (3): Demographic Data of Respondents.

\begin{tabular}{|c|c|c|c|c|}
\hline \multirow[t]{2}{*}{ Demographic Data } & \multirow[t]{2}{*}{ Attribute } & \multicolumn{2}{|c|}{ Statistics } & \multirow[t]{2}{*}{ Rank } \\
\hline & & Freq. & $\%$ & \\
\hline \multirow[t]{2}{*}{ Gender } & Male & 285 & 57.0 & 1 \\
\hline & Female & 215 & 43.0 & 2 \\
\hline \multicolumn{2}{|r|}{ Total } & 500 & \multicolumn{2}{|c|}{$100 \%$} \\
\hline \multirow{5}{*}{ Age } & From 20-30 years & 137 & 27.4 & 3 \\
\hline & From 31-40 years & 189 & 37.8 & 1 \\
\hline & From $41-50$ years & 144 & 28.8 & 2 \\
\hline & From 51-60 years & 21 & 4.2 & 4 \\
\hline & More than 60 years & 9 & 1.8 & 5 \\
\hline \multicolumn{2}{|r|}{ Total } & 500 & \multicolumn{2}{|c|}{$100 \%$} \\
\hline \multirow{3}{*}{ Museum } & Luxor Museum & 339 & 67.8 & 1 \\
\hline & Mummification Museum & 53 & 10.6 & 3 \\
\hline & Nubian Museum & 69 & 13.8 & 2 \\
\hline
\end{tabular}




\begin{tabular}{|r||c|c|c|c|}
\hline & Sohag National Museum & 32 & 6.4 & 4 \\
\cline { 2 - 5 } & Others & 7 & 1.4 & 5 \\
\hline \hline Total & $\mathbf{5 0 0}$ & $\mathbf{1 0 0 \%}$ \\
\hline
\end{tabular}

The results in table (3) indicated that $57 \%$ of the respondents were male, and $43 \%$ were female. Regarding the age of respondents, $37.8 \%$ of the respondents were between 31-40 years, followed by who were from $41-$ 50 years by $28.8 \%$, then who were between $20-30$ years by $27.4 \%$, then who were between $51-60$ years by $4.2 \%$, and finally, who were more than 60 years by $1.8 \%$. Respondents' Museums included the following: Luxor Museum 67.8\%, Nubian Museum 13.8\%, Mummification Museum 10.6\%, Sohag National Museum 6.4\%, and Others $1.4 \%$ which are Mallawi Museum and Karnak temple and open-air museum.

Table (4): The First Visit to the Museum

\begin{tabular}{|c||c||c|c|c|}
\hline Factor & Variables & Frequency & Percentage (\%) & Rank \\
\hline \hline $\begin{array}{c}\text { Is this your 1 } \\
\text { st time to } \\
\text { visit this museum? }\end{array}$ & Yes & 135 & 27.0 & 2 \\
\cline { 2 - 5 } & No & 365 & 73.0 & 1 \\
\hline \hline \multicolumn{2}{|c|}{ Total } & $\mathbf{5 0 0}$ & $\mathbf{1 0 0 \%}$ & - \\
\hline
\end{tabular}

The results of table (4) showed that the majority of respondents $73 \%$ have visited the museum before; meanwhile $27 \%$ were their first visit.

Table (5): Number of Previous Visits

\begin{tabular}{|c||c||c|c|c|}
\hline Factor & Variables & Frequency & Percentage (\%) & Rank \\
\hline \hline \multirow{2}{*}{$\begin{array}{c}\text { How many times } \\
\text { hove you visited this } \\
\text { museum before? }\end{array}$} & Once & 5 & 1.4 & 4 \\
\cline { 2 - 5 } & Twice & 44 & 12.1 & 3 \\
\cline { 2 - 5 } & $\begin{array}{c}\text { more than 3 } \\
\text { times }\end{array}$ & 57 & 15.6 & 2 \\
\hline \hline \multicolumn{2}{|c|}{ Total } & $\mathbf{3 6 5}$ & 71.0 & 1 \\
\hline \multicolumn{2}{|c|}{} & $\mathbf{1 0 0 \%}$ & - \\
\hline
\end{tabular}

$* \mathbf{N}=365$

The results illustrated that the number of visits which were more than 3 times is the highest number for respondents' evaluation $71.0 \%$, three times is the second by $15.6 \%$ while 2 times visit is the third value $12.1 \%$ and finally once by $1.4 \%$. 


\section{THIRD: DIMENSIONS OF THE RESEARCH}

\section{TANGIBILITY}

It is noticed from the below table (6) that the mean reveals to the degree of respondents' agreement about the statements. The standard deviation reveals the harmony of respondents' opinions. The (t-test) p-value shows a significant for the mean and the standard deviation. Data presented in table (6) revealed that there was a significant difference among respondents' answers $(\mathrm{p}<0.05)$.

Results in table (6) illustrated that the responses of research sample (regarding museum) according to the mean are with the highest level of agreement with the cleanness of the museum's environment (inside and outside) by (mean $=4.00 \& \mathrm{SD}=.90$ ), then with the adequacy of the distance between exhibits and visitors (mean=3.87) then followed by the attractiveness of the museum building and being modern by (mean= 3.83). They were neutral on the presence of souvenir and craft centre there by $($ mean $=3.24)$, then the presence of sufficient parking areas by (mean= 3.22). Museum produces brochures with different languages and printed guide comes next by (mean= 3.12). Thus, the average mean of all the statements of museum's appearance were towards approval at (mean= $3.53 \& \mathrm{SD}=1.02)$. 
Table (6): Tangibility Dimension Responses

\begin{tabular}{|c|c|c|c|c|c|c|c|c|c|}
\hline \multirow{2}{*}{ Statements } & & \multicolumn{5}{|c|}{ 5-Point Likert - Scale } & \multicolumn{3}{|c|}{ Statistics } \\
\hline & & 1 & 2 & 3 & 4 & 5 & $\overline{\mathbf{x}}$ & SD & $\mathbf{R}$ \\
\hline \multicolumn{10}{|c|}{ Regarding Museum } \\
\hline \multirow{2}{*}{ Museum itself has modern and attractive building. } & Freq. & 21 & 25 & 110 & 205 & 139 & \multirow{2}{*}{3.83} & \multirow{2}{*}{1.025} & \multirow{2}{*}{3} \\
\hline & $\%$ & 4.2 & 5 & 22 & 41 & 27.8 & & & \\
\hline \multirow{2}{*}{ Museum has visually attractive facilities. } & Freq. & 28 & 70 & 112 & 172 & 118 & \multirow{2}{*}{3.56} & \multirow{2}{*}{1.156} & \multirow{2}{*}{10} \\
\hline & $\%$ & 5.6 & 14 & 22.4 & 34.4 & 23.6 & & & \\
\hline \multirow{2}{*}{ The distance between exhibits and visitors is adequate. } & Freq. & 15 & 11 & 130 & 213 & 131 & \multirow{2}{*}{3.87} & \multirow{2}{*}{.930} & \multirow{2}{*}{2} \\
\hline & $\%$ & 3 & 2.2 & 26 & 42.6 & 26.2 & & & \\
\hline \multirow{2}{*}{ Crowdedness level is accepted. } & Freq. & 9 & 29 & 118 & 229 & 115 & \multirow{2}{*}{3.82} & \multirow{2}{*}{.911} & \multirow{2}{*}{4} \\
\hline & $\%$ & 1.8 & 5.8 & 23.6 & 45.8 & 23 & & & \\
\hline \multirow{2}{*}{ Museum has useful orientation signs. } & Freq. & 8 & 31 & 121 & 241 & 99 & \multirow{2}{*}{3.78} & \multirow{2}{*}{.887} & \multirow{2}{*}{6} \\
\hline & $\%$ & 1.6 & 6.2 & 24.2 & 48.2 & 19.8 & & & \\
\hline \multirow{2}{*}{ Museum's environment is clean (inside and outside). } & Freq. & 9 & 19 & 95 & 219 & 158 & \multirow{2}{*}{4.00} & \multirow{2}{*}{.906} & \multirow{2}{*}{1} \\
\hline & $\%$ & 1.8 & 3.8 & 19 & 43.8 & 31.6 & & & \\
\hline \multirow{2}{*}{ Museum has sufficient parking areas. } & Freq. & 67 & 70 & 150 & 111 & 102 & \multirow{2}{*}{3.22} & \multirow{2}{*}{1.292} & \multirow{2}{*}{15} \\
\hline & $\%$ & 13.4 & 14 & 30 & 22.2 & 20.4 & & & \\
\hline \multirow{2}{*}{ Museum has clean resting rooms. } & Freq. & 32 & 45 & 179 & 170 & 74 & \multirow{2}{*}{3.42} & 1051 & 13 \\
\hline & $\%$ & 6.4 & 9 & 35.8 & 34 & 14.8 & & $1.0 \supset 1$ & 15 \\
\hline & Freq. & 46 & 131 & 176 & 102 & 45 & & & \\
\hline Museum has no restriction areas (free exploitation). & $\%$ & 9.2 & 26.2 & 35.2 & 20.4 & 9 & 2.94 & 1.092 & 18 \\
\hline
\end{tabular}




\begin{tabular}{|c|c|c|c|c|c|c|c|c|c|}
\hline \multirow{2}{*}{\multicolumn{2}{|c|}{ Statements }} & \multicolumn{5}{|c|}{ 5-Point Likert - Scale } & \multicolumn{3}{|c|}{ Statistics } \\
\hline & & \multirow{2}{*}{$\begin{array}{c}1 \\
21\end{array}$} & \multirow{2}{*}{\begin{tabular}{|c|}
$\mathbf{2}$ \\
37 \\
\end{tabular}} & \multirow{2}{*}{\begin{tabular}{|c|}
$\mathbf{3}$ \\
112 \\
\end{tabular}} & \multirow{2}{*}{\begin{tabular}{c|}
4 \\
186
\end{tabular}} & \multirow{2}{*}{\begin{tabular}{c|}
5 \\
144
\end{tabular}} & \multirow{3}{*}{$\begin{array}{c}\overline{\mathbf{x}} \\
3.79\end{array}$} & \multirow{3}{*}{$\begin{array}{c}\text { SD } \\
1.070\end{array}$} & \multirow{3}{*}{$\begin{array}{l}\mathbf{R} \\
5\end{array}$} \\
\hline Museum reflects a historical atmosphere for the & Freq. & & & & & & & & \\
\hline displayed pieces. & $\%$ & 4.2 & 7.4 & 22.4 & 37.2 & 28.8 & & & \\
\hline \multirow{2}{*}{ Museum has lighting distribution quality. } & Freq. & 25 & 25 & 156 & 181 & 113 & \multirow{2}{*}{3.66} & \multirow{2}{*}{1.038} & \multirow{2}{*}{8} \\
\hline & $\%$ & 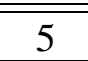 & 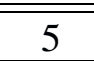 & 31.2 & 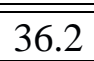 & 222.6 & & & \\
\hline \multirow{2}{*}{ Museum has good ventilation and air conditioning. } & Freq. & 11 & 56 & 171 & 152 & 110 & \multirow{2}{*}{3.59} & \multirow{2}{*}{1.020} & \multirow{2}{*}{9} \\
\hline & $\%$ & 2.2 & 11.2 & 34.2 & 30.4 & 22 & & & \\
\hline \multirow{2}{*}{ Museum has introductory plaque on its building. } & Freq. & 5 & 57 & 197 & 154 & 87 & \multirow{2}{*}{3.52} & \multirow{2}{*}{.942} & \multirow{2}{*}{11} \\
\hline & $\%$ & 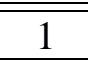 & 111.4 & 39.4 & 30.8 & $17 \overline{17.4}$ & & & \\
\hline \multirow{2}{*}{ Museum has a timeline for its working hours. } & Freq. & 10 & 36 & 154 & 188 & 112 & \multirow{2}{*}{3.71} & \multirow{2}{*}{.959} & \multirow{2}{*}{7} \\
\hline & $\%$ & 2 & 7.2 & 30.8 & 37.6 & 22.4 & & & \\
\hline \multirow{2}{*}{$\begin{array}{l}\text { Museum produces brochures with different languages } \\
\text { and printed guide. }\end{array}$} & Freq. & 37 & 92 & 205 & 107 & 59 & \multirow{2}{*}{3.12} & \multirow{2}{*}{1.074} & \multirow{2}{*}{16} \\
\hline & $\%$ & 7.4 & 18.4 & 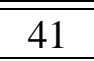 & 21.4 & 11.8 & & & \\
\hline \multirow{2}{*}{$\begin{array}{l}\text { Museum sells relevant replicas and archaeological } \\
\text { books. }\end{array}$} & Freq. & 54 & 64 & 225 & 128 & 29 & \multirow{2}{*}{3.03} & \multirow{2}{*}{1.024} & \\
\hline & $\%$ & 10.8 & 12.8 & 45 & 25.6 & 5.8 & & & 17 \\
\hline Museum has sufficient paths that facilitate visitor's & Freq. & 20 & 59 & 182 & 155 & 84 & 3.15 & 1030 & 12 \\
\hline access and ensure the safety of the exhibits. & $\%$ & 4 & 11.8 & ב36.4 & 31 & 16.8 & 3.45 & 1.030 & 12 \\
\hline & Freq. & 34 & 84 & 156 & 180 & 46 & & & \\
\hline Museum has souvenir and craft center. & $\%$ & 6.8 & 16.8 & 31.2 & 36 & 9.2 & 3.24 & 1.055 & 14 \\
\hline & & & & & & & 3.53 & 1.025 & - \\
\hline
\end{tabular}




\begin{tabular}{|c|c|c|c|c|c|c|c|c|c|}
\hline \multirow{2}{*}{\multicolumn{2}{|c|}{ Statements }} & \multicolumn{5}{|c|}{ 5-Point Likert - Scale } & \multicolumn{3}{|c|}{ Statistics } \\
\hline & & 1 & 2 & 3 & 4 & 5 & $\overline{\mathbf{x}}$ & SD & $\mathbf{R}$ \\
\hline \multicolumn{10}{|c|}{ Regarding Exhibits } \\
\hline \multirow{2}{*}{$\begin{array}{l}\text { Museum has attractive exhibition's content and pre- } \\
\text { occupied with your best interests. }\end{array}$} & Freq. & 38 & 41 & 110 & 241 & 70 & \multirow{2}{*}{3.53} & \multirow{2}{*}{1.073} & \multirow{2}{*}{5} \\
\hline & $\%$ & 7.6 & 8.2 & 22 & 48.2 & 14 & & & \\
\hline \multirow{2}{*}{ Exhibits are properly ordered. } & Freq. & 38 & 53 & 122 & 227 & 60 & \multirow{2}{*}{3.44} & \multirow{2}{*}{1.075} & \multirow{2}{*}{6} \\
\hline & $\%$ & 7.6 & 10.6 & 24.4 & 45.4 & 12 & & & \\
\hline \multirow{2}{*}{$\begin{array}{l}\text { Pieces shown in the museum are compatible (suitable) } \\
\text { with the space. }\end{array}$} & Freq. & 26 & 45 & 114 & 244 & 71 & \multirow{2}{*}{3.58} & \multirow{2}{*}{1.011} & \multirow{2}{*}{4} \\
\hline & $\%$ & 5.2 & 9 & 22.8 & 48.8 & 14.2 & & & \\
\hline \multirow{2}{*}{$\begin{array}{l}\text { Pieces of the museum have distinct artistic value and } \\
\text { related to the region to which the museum belongs to. }\end{array}$} & Freq. & 19 & 31 & 108 & 232 & 110 & \multirow{2}{*}{3.77} & \multirow{2}{*}{.987} & \multirow{2}{*}{1} \\
\hline & $\%$ & 3.8 & 6.2 & 21.6 & 46.4 & 22 & & & \\
\hline \multirow{2}{*}{ Pieces of the museum coincide with its theme. } & Freq. & 10 & 44 & 145 & 211 & 90 & \multirow{2}{*}{3.65} & \multirow{2}{*}{.940} & \multirow{2}{*}{2} \\
\hline & $\%$ & 2 & 8.8 & 29 & $\overline{242.2}$ & 18 & & & \\
\hline \multirow{2}{*}{$\begin{array}{c}\text { A proper scientific method is used to clarify museum } \\
\text { pieces. }\end{array}$} & Freq. & 11 & 30 & 192 & 183 & 84 & \multirow{2}{*}{3.60} & \multirow{2}{*}{.911} & \multirow{2}{*}{3} \\
\hline & $\%$ & 2.2 & 6 & 38.4 & 36.6 & 16.8 & & & \\
\hline & & & & & & & 3.60 & 0.999 & - \\
\hline \multicolumn{10}{|c|}{ Regarding Displayed Cabinets } \\
\hline \multirow{2}{*}{$\begin{array}{l}\text { Displayed cabinets are good designed and of good } \\
\text { quality. }\end{array}$} & Freq. & 21 & 58 & 171 & 173 & 77 & \multirow{2}{*}{3.45} & \multirow{2}{*}{1.021} & \multirow{2}{*}{3} \\
\hline & $\%$ & 4.2 & 111.6 & 34.2 & 34.6 & 15.4 & & & \\
\hline \multirow{2}{*}{$\begin{array}{l}\text { Pieces are displayed correctly and are distributed in } \\
\text { proportion to the halls of the museum. }\end{array}$} & Freq. & 20 & 51 & 150 & 191 & 88 & & & \\
\hline & $\%$ & 4 & $\begin{array}{l}10.2 \\
\end{array}$ & 30 & 38.2 & $\begin{array}{l}17.6 \\
\end{array}$ & 3.55 & 1.022 & 2 \\
\hline
\end{tabular}




\begin{tabular}{|c|c|c|c|c|c|c|c|c|c|}
\hline \multirow{2}{*}{\multicolumn{2}{|c|}{ Statements }} & \multicolumn{5}{|c|}{ 5-Point Likert - Scale } & \multicolumn{3}{|c|}{ Statistics } \\
\hline & & \multirow{2}{*}{1} & \multirow{2}{*}{\begin{tabular}{c|}
2 \\
36 \\
\end{tabular}} & \multirow{2}{*}{$\begin{array}{c}3 \\
182 \\
\end{array}$} & \multirow{2}{*}{\begin{tabular}{c|c|}
4 \\
185 \\
\end{tabular}} & \multirow{2}{*}{$\begin{array}{c}5 \\
87 \\
\end{array}$} & \multirow{3}{*}{$\overline{\overline{\mathbf{x}}}$} & \multirow{3}{*}{$\begin{array}{l}\text { SD } \\
923\end{array}$} & \multirow{3}{*}{$\begin{array}{l}\mathbf{R} \\
1\end{array}$} \\
\hline \multirow{2}{*}{$\begin{array}{l}\text { The displayed cabinets are proportional to the size of } \\
\text { the exhibits that ensure their safety. }\end{array}$} & Freq. & & & & & & & & \\
\hline & $\%$ & 2 & 7.2 & 36.4 & 37 & 17.4 & & & \\
\hline & & & & & & & 3.54 & 0.989 & - \\
\hline \multicolumn{10}{|c|}{ Regarding Cafes and bazars (If present) * } \\
\hline \multirow{2}{*}{ Cafe or restaurant is good equipped } & Freq. & 242 & 57 & 96 & 76 & 29 & \multirow{2}{*}{2.19} & \multirow{2}{*}{1.332} & \multirow{2}{*}{4} \\
\hline & $\%$ & 48.4 & 11.4 & 19.2 & 15.2 & 5.8 & & & \\
\hline \multirow{2}{*}{$\begin{array}{l}\text { Cafe or restaurant presents delicious and various kinds } \\
\text { of food and beverage. }\end{array}$} & Freq. & 244 & 47 & 107 & 64 & 38 & \multirow{2}{*}{2.21} & \multirow{2}{*}{1.363} & \multirow{2}{*}{3} \\
\hline & $\%$ & 48.8 & 9.4 & 21.4 & 12.8 & 7.6 & & & \\
\hline \multirow{2}{*}{ Bazars are good equipped. } & Freq. & 197 & 34 & 97 & 138 & 34 & \multirow{2}{*}{2.56} & \multirow{2}{*}{1.414} & \multirow{2}{*}{2} \\
\hline & $\%$ & 39.4 & 6.8 & 19.4 & 27.6 & 6.8 & & & \\
\hline \multirow{2}{*}{ Bazars contain various kinds of souvenirs. } & Freq. & 186 & 34 & 96 & 150 & 34 & \multirow{2}{*}{2.62} & \multirow{2}{*}{1.411} & \multirow{2}{*}{1} \\
\hline & $\%$ & 37.3 & 6.8 & 19.2 & 29.9 & 6.8 & & & \\
\hline & & & & & & & 2.40 & 1.380 & - \\
\hline \multicolumn{7}{|c|}{ Tangibility Average Mean } & \multicolumn{3}{|c|}{$\begin{array}{l}3.56 \\
\end{array}$} \\
\hline \multicolumn{10}{|c|}{$\begin{array}{l}\text { N.B: } 1=" \text { Strongly Disagree", 2=" Disagree, 3="Neutral", 4="Agree, 5= "Strongly Agree", SD, "Standard Deviation". R=Rank, } \\
\overline{\mathbf{x}}=\text { Mean } \\
\text { N.B:*: } 1=" \text { Not exist", 2=" Weakly exist, 3="moderately existl", 4="Exist, } 5=\text { "Perfectly exist", SD, "Standard Deviation". } \\
\text { R=Rank, } \overline{\mathbf{x}}=\text { Mean }\end{array}$} \\
\hline
\end{tabular}


Results in table (6) showed that the responses of research sample (regarding the exhibits) according to the mean agree with the following statements with the highest level of agreement as follows " Pieces of the museum have distinct artistic value and related to the region to which the museum belongs to) by (mean= 3.77\& $\mathrm{SD}=.987)$, then the statement of "Pieces of the museum coincide with its theme.) by $($ mean $=3.65)$ followed by the presence of a scientific method to clarify the pieces with (mean= 3.60 and SD $=0.911$ ). All the statements regarding (Exhibits) were towards approval, at (Mean $=3.60 \& \mathrm{SD}=.99$ ).

As seen in table (6) the results showed that the responses of research (regarding the displayed cabinets) according to the mean, the highest level of agreement was for "The displayed cabinets are proportional to the size of the exhibits that ensure their safety) by (mean= 3.61\& $\mathrm{SD}=.92$ ), then the statement for the pieces that are displayed correctly and are distributed in proportion to the halls of the museum by (mean= 3.55). The average mean of all the statements regarding the (Displayed Cabinets) were towards approval, at (mean $=3.54 \& \mathrm{SD}=.98)$.

Regarding Cafes and bazars (in case of presence) according to the mean, the following statements have the level of moderately exist as follows: "Bazars contain various kinds of souvenirs) by (mean $=2.62 \& \mathrm{SD}=1.41$ ). On the other side the answers of respondents were weakly exist on the following statement "Bazars are good equipped) by (mean=2.56) followed by the statement of "Cafe or restaurant presents delicious and various kinds of food and beverage" by $($ mean $=2.21)$. The average mean of all the statements regarding Cafes and bazars (in case of presence) were towards weakly exist at (mean $=2.40 \& \mathrm{SD}=1.38$ ). Thus, the average mean of the statements of (Tangibility dimension) were towards approval at (mean=3.56).

\section{RELIABILITY DIMENSION}

Table (7): Reliability Dimension Responses

\begin{tabular}{|c|c|c|c|c|c|c|c|c|c|}
\hline \multirow{2}{*}{\multicolumn{2}{|c|}{ Statements }} & \multicolumn{5}{|c|}{ 5-Point Likert - Scale } & \multicolumn{3}{|c|}{ Statistics } \\
\hline & & $\overline{1}$ & 2 & 3 & 4 & 5 & $\overline{\overline{\mathbf{x}}}$ & SD & $\mathbf{R}$ \\
\hline \multirow{2}{*}{$\begin{array}{l}\text { The promised } \\
\text { deliveries are } \\
\text { met in due } \\
\text { time. }\end{array}$} & Freq. & 10 & 43 & 225 & 179 & 43 & \multirow[b]{2}{*}{3.40} & \multirow[b]{2}{*}{.840} & \multirow[b]{2}{*}{2} \\
\hline & $\%$ & 2 & 8.6 & 45 & 35.8 & 8.6 & & & \\
\hline \multirow{2}{*}{$\begin{array}{l}\text { You were } \\
\text { informed } \\
\text { about when } \\
\text { the service } \\
\text { will be } \\
\text { provided. }\end{array}$} & Freq. & 24 & 55 & 183 & 204 & 34 & \multirow[b]{2}{*}{3.34} & \multirow[b]{2}{*}{.932} & \multirow[b]{2}{*}{3} \\
\hline & $\%$ & 4.8 & 11 & 36.6 & 40.8 & 6.8 & & & \\
\hline
\end{tabular}




\begin{tabular}{|c|c|c|c|c|c|c|c|c||c|}
\hline $\begin{array}{c}\text { The guide's } \\
\text { narration was } \\
\text { easy to follow. }\end{array}$ & Freq. & 4 & 27 & 159 & 220 & 90 & & \\
\hline \hline & 0.8 & 5.4 & 31.8 & 44 & 18 & 3.73 & .845 & 1 \\
\hline \hline
\end{tabular}

N.B: 1="Strongly Disagree", 2=" Disagree, 3="Neutral", 4="Agree, 5= "Strongly Agree", SD, "Standard Deviation". R=Rank, $\overline{\mathbf{x}}=$ Mean

Results in table (7) illustrated that the responses of research sample agree with the statements of the reliability dimension according to the mean, the highest level of agreement with the statement "The guide's narration was easy to follow) by (mean $=3.73 \& \mathrm{SD}=.84$ ), meanwhile the responses of research sample were neutral with the statement of "The promised deliveries are met in due time) by (mean=3.40). The average mean of the statements of (Reliability dimension) were towards approval at (mean= 3.49).

\section{RESPONSIVENESS DIMENSION}

Table (8): Responsiveness Dimension Responses

\begin{tabular}{|c|c|c|c|c|c|c|c|c|c|}
\hline \multirow{2}{*}{\multicolumn{2}{|c|}{ Statements }} & \multicolumn{5}{|c|}{ 5-Point Likert - Scale } & \multicolumn{3}{|c|}{ Statistics } \\
\hline & & \multirow{2}{*}{$\begin{array}{c}1 \\
245 \\
\end{array}$} & \multirow{2}{*}{$\begin{array}{c}2 \\
13 \\
\end{array}$} & \multirow{2}{*}{$\begin{array}{c}\mathbf{3} \\
111 \\
\end{array}$} & \multirow{2}{*}{$\begin{array}{c}4 \\
88 \\
\end{array}$} & \multirow{2}{*}{$\begin{array}{c}\mathbf{5} \\
43 \\
\end{array}$} & \multirow[t]{2}{*}{$\overline{\mathbf{x}}$} & \multirow[t]{2}{*}{ SD } & \multirow[t]{2}{*}{$\overline{\mathbf{R}}$} \\
\hline \multirow{2}{*}{$\begin{array}{c}\text { Staff of café } \\
\text { gave you } \\
\text { prompt } \\
\text { service }\end{array}$} & Freq. & & & & & & & & \\
\hline & $\%$ & 49 & 2.6 & 22.2 & 17.6 & 8.6 & 2.34 & 1.441 & 4 \\
\hline \multirow{2}{*}{$\begin{array}{l}\text { Staff of café } \\
\text { showed } \\
\text { good willing } \\
\text { to assist you }\end{array}$} & Freq. & 235 & 4 & 106 & 106 & 49 & \multirow[b]{2}{*}{2.46} & \multirow[b]{2}{*}{1.485} & \multirow[b]{2}{*}{3} \\
\hline & $\%$ & 47 & 0.8 & 21.2 & 21.2 & 9.8 & & & \\
\hline \multirow{2}{*}{$\begin{array}{c}\text { Staff of } \\
\text { bazars gave } \\
\text { you prompt } \\
\text { service }\end{array}$} & Freq. & 200 & 10 & 104 & 138 & 48 & \multirow[b]{2}{*}{2.65} & \multirow[b]{2}{*}{1.470} & \multirow[b]{2}{*}{2} \\
\hline & $\%$ & 40 & 2 & 20.8 & 27.6 & 9.6 & & & \\
\hline \multirow{2}{*}{$\begin{array}{c}\text { Staff of } \\
\text { bazars } \\
\text { showed } \\
\text { good willing } \\
\text { to assist you } \\
\end{array}$} & Freq. & 195 & 10 & 93 & 149 & 53 & \multirow[b]{2}{*}{2.71} & \multirow[b]{2}{*}{1.491} & \multirow[b]{2}{*}{1} \\
\hline & $\%$ & 39.1 & 2 & 18.6 & 29.7 & 10.6 & & & \\
\hline \multicolumn{7}{|c|}{ Average Mean } & 2.54 & 1.471 & 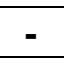 \\
\hline N.B: $1=" \mathrm{~N}$ & & $2=" 1$ & & & & & & t=" Ex & \\
\hline
\end{tabular}




\section{"Perfectly exist",, SD, "Standard Deviation". R=Rank, $\overline{\mathbf{x}}=$ Mean}

The results in table (8) showed that the answers of respondents were moderately exist on the statement that is related to the good willing of bazars' staff to assist you by (mean= 2.71), then the statement that is related to the prompt service of bazars' staff by (mean=2.65). On the other side the answers of respondents were weakly exist on the statement of the good willing of cafes' staff to assist you by (mean=2.46), then the statement that is related to the prompt service provided by cafes' staff by $($ mean $=2.34)$. The average mean of all the statements of (Responsiveness dimension) were towards weakly exist at (mean=2.54).

\section{ASSURANCE DIMENSION}

Table (9): Assurance Dimension Responses

\begin{tabular}{|c|c|c|c|c|c|c|c|c|c|}
\hline \multirow{2}{*}{\multicolumn{2}{|c|}{ Statements }} & \multicolumn{5}{|c|}{ 5-Point Likert - Scale } & \multicolumn{3}{|c|}{ Statistics } \\
\hline & & \multirow{2}{*}{$\begin{array}{c}\mathbf{1} \\
240\end{array}$} & \multirow{2}{*}{$\begin{array}{l}\mathbf{2} \\
8\end{array}$} & \multirow{2}{*}{\begin{tabular}{|c|}
$\mathbf{3}$ \\
112
\end{tabular}} & \multirow{2}{*}{$\begin{array}{c}4 \\
91\end{array}$} & \multirow{2}{*}{$\begin{array}{l}5 \\
49\end{array}$} & \multirow[b]{3}{*}{2.40} & SD & $\mathbf{R}$ \\
\hline Staff of cafes & Freq. & & & & & & & \multirow[b]{2}{*}{1.46} & \multirow[b]{2}{*}{3} \\
\hline $\begin{array}{c}\text { knowledgeable } \\
\text { enough about } \\
\text { items present }\end{array}$ & $\%$ & 47.9 & 1.6 & 22.4 & 18.2 & 9.8 & & & \\
\hline \multirow{2}{*}{$\begin{array}{c}\text { Staff of bazars } \\
\text { was } \\
\text { knowledgeable } \\
\text { enough about } \\
\text { souvenirs } \\
\end{array}$} & Freq. & 188 & 10 & 111 & 138 & 53 & \multirow[b]{2}{*}{2.72} & \multirow[b]{2}{*}{1.46} & \multirow[b]{2}{*}{2} \\
\hline & $\%$ & 37.5 & 2 & 22.2 & 27.7 & 10.6 & & & \\
\hline \multirow{2}{*}{$\begin{array}{c}\text { Tour guide is } \\
\text { professional } \\
\text { and } \\
\text { knowledgeable } \\
\text { to explain the } \\
\text { pieces. }\end{array}$} & Freq. & 19 & 10 & 139 & 232 & 100 & \multirow[b]{2}{*}{3.77} & \multirow[b]{2}{*}{.92} & \multirow[b]{2}{*}{1} \\
\hline & $\%$ & 3.8 & 2 & 27.8 & 46.4 & 20 & & & \\
\hline \multicolumn{7}{|c|}{ Average Mean } & 2.96 & 1.28 & - \\
\hline
\end{tabular}

Results in table (9) illustrated that the responses of research sample with the statements of Assurance dimension according to the mean, the following statement has the highest level of perfectly exist is that the tour guide is professional and knowledgeable to explain the pieces by (mean= 
$3.77 \& \mathrm{SD}=.92)$. Meanwhile the answers of respondents were moderately exist towards the statement of the bazars' staff was knowledgeable enough about souvenirs by $($ mean= 2.72). On the other side their answers were weakly exist on the statement that is related to the cafes' staff was knowledgeable enough about items present by $($ mean $=2.40)$. The average mean of all the statements of (Assurance dimension) were moderately exist present by (mean $=2.96)$.

\section{EMPATHY DIMENSION}

Table (10): Empathy Dimension Responses

\begin{tabular}{|c|c|c|c|c|c|c|c|c|c|}
\hline \multirow{2}{*}{\multicolumn{2}{|c|}{ Statements }} & \multicolumn{5}{|c|}{ 5-Point Likert - Scale } & \multicolumn{3}{|c|}{ Statistics } \\
\hline & & \multirow{2}{*}{$\begin{array}{c}1 \\
240\end{array}$} & \multirow{2}{*}{$\frac{\mathbf{2}}{10}$} & \multirow{2}{*}{$\frac{3}{3}$} & \multirow{2}{*}{$\begin{array}{c}4 \\
114\end{array}$} & \multirow{2}{*}{$\begin{array}{c}\mathbf{5} \\
39\end{array}$} & \multirow[t]{2}{*}{$\overline{\mathbf{x}}$} & \multirow[t]{2}{*}{ SD } & \multirow[t]{2}{*}{$\mathbf{R}$} \\
\hline Staff of & Freq. & & & & & & & & \\
\hline $\begin{array}{l}\text { caté gave } \\
\text { you } \\
\text { individual } \\
\text { attention } \\
\text { and } \\
\text { understood } \\
\text { your needs. }\end{array}$ & $\%$ & 48 & 2 & 19.4 & 22.8 & 7.8 & 2.40 & 1.459 & 4 \\
\hline \multirow{2}{*}{$\begin{array}{c}\text { Staff of } \\
\text { café was } \\
\text { courteous } \\
\text { and polite. }\end{array}$} & Freq. & 208 & 13 & 123 & 98 & 58 & \multirow[b]{2}{*}{2.57} & \multirow[b]{2}{*}{1.473} & \multirow[b]{2}{*}{3} \\
\hline & $\%$ & 41.6 & 2.6 & 24.6 & 19.6 & 11.6 & & & \\
\hline \multirow[b]{2}{*}{$\begin{array}{c}\text { Staff of } \\
\text { bazars gave } \\
\text { you } \\
\text { individual } \\
\text { attention } \\
\text { and } \\
\text { understood } \\
\text { your needs. }\end{array}$} & Freq. & 188 & 20 & 93 & 146 & 53 & \multirow[b]{2}{*}{2.71} & \multirow[b]{2}{*}{1.477} & \multirow[b]{2}{*}{2} \\
\hline & $\%$ & 37.6 & 4 & 18.6 & 29.2 & 10.6 & & & \\
\hline \multirow{2}{*}{$\begin{array}{c}\text { Staff of } \\
\text { bazars was } \\
\text { courteous } \\
\text { and polite }\end{array}$} & Freq. & 156 & 15 & 121 & 156 & 52 & \multirow[b]{2}{*}{2.87} & \multirow[b]{2}{*}{1.411} & \multirow[b]{2}{*}{1} \\
\hline & $\%$ & 31.2 & 3 & 24.2 & 31.2 & 10.4 & & & \\
\hline \multicolumn{7}{|c|}{ Average Mean } & 2.64 & 1.455 & - \\
\hline
\end{tabular}


Table (10) clarified that the answers were moderately exist on the courtesy and politeness of staff bazars by (mean= 2.87), then the individual attention provided by bazars' staff in understanding visitors' needs by (mean=2.71). On the other side the answers of respondents were weakly exist as follow: the courtesy and politeness of cafes' staff by (mean=2.57), then the statement that is related in providing individual attention to visitors by $($ mean $=2.40)$. The average mean of all the statements of (Empathy dimension) were moderately exist by $($ mean $=2.64)$.

\section{COMPLEMENTARY SERVICES}

Table (11): Respondents' answers on Complementary Services

\begin{tabular}{|c|c|c|c|c|c|c|c|c|c|}
\hline \multirow{2}{*}{\multicolumn{2}{|c|}{ Statements }} & \multicolumn{5}{|c|}{ 5-Point Likert - Scale } & \multicolumn{3}{|c|}{ Statistics } \\
\hline & & \multirow{2}{*}{$\begin{array}{c}1 \\
52 \\
\end{array}$} & \multirow{2}{*}{\begin{tabular}{c|}
2 \\
154 \\
\end{tabular}} & \multirow{2}{*}{\begin{tabular}{|c|}
$\mathbf{3}$ \\
131 \\
\end{tabular}} & \multirow{2}{*}{\begin{tabular}{c|}
4 \\
104 \\
\end{tabular}} & \multirow{2}{*}{$\begin{array}{c}5 \\
59 \\
\end{array}$} & \multirow[t]{2}{*}{$\overline{\mathbf{x}}$} & \multirow{2}{*}{ 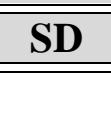 } & \multirow[t]{2}{*}{$\mathbf{R}$} \\
\hline Museum has & Freq. & & & & & & & & \\
\hline $\begin{array}{l}\text { entertainment areas } \\
\text { (gardens, movie } \\
\text { theatre)....etc. }\end{array}$ & $\%$ & 10.4 & 30.8 & 26.2 & 20.8 & 11.8 & 2.93 & 1.184 & 4 \\
\hline \multirow{2}{*}{$\begin{array}{c}\text { Museum has audio } \\
\text { guiding }\end{array}$} & Freq. & 88 & 142 & 128 & 76 & 66 & \multirow{2}{*}{2.78} & \multirow{2}{*}{1.274} & \multirow[b]{2}{*}{7} \\
\hline & $\%$ & 17.6 & 28.4 & 25.6 & 15.2 & 13.2 & & & \\
\hline \multirow{2}{*}{$\begin{array}{c}\text { Museum has } \\
\text { internet connection. }\end{array}$} & Freq. & 114 & 158 & 88 & 90 & 50 & \multirow{2}{*}{2.61} & \multirow{2}{*}{1.287} & \multirow[b]{2}{*}{9} \\
\hline & $\%$ & 22.8 & $\overline{31.6}$ & $\overline{17.6}$ & 18 & 10 & & & \\
\hline \multirow{2}{*}{$\begin{array}{c}\text { Museum is } \\
\text { accessible for } \\
\text { elderly and disabled } \\
\text { visitors. }\end{array}$} & Freq. & 21 & 57 & 157 & 159 & 106 & \multirow[b]{2}{*}{3.54} & \multirow[b]{2}{*}{1.074} & \multirow[b]{2}{*}{1} \\
\hline & $\%$ & 4.2 & 11.4 & 31.4 & 31.8 & 21.2 & & & \\
\hline \multirow{2}{*}{$\begin{array}{l}\text { Museum represents } \\
\text { a cultural hub for } \\
\text { workshops, art } \\
\text { galleries and } \\
\text { cultural salons. }\end{array}$} & Freq. & 56 & 94 & 135 & 152 & 63 & \multirow[b]{2}{*}{3.14} & \multirow[b]{2}{*}{1.194} & \multirow[b]{2}{*}{2} \\
\hline & $\%$ & 11.2 & 18.8 & 27 & 30.4 & 12.6 & & & \\
\hline \multirow{2}{*}{$\begin{array}{c}\text { Museum has mobile } \\
\text { applications. }\end{array}$} & Freq. & 101 & 173 & 122 & 64 & 40 & \multirow{2}{*}{2.54} & \multirow{2}{*}{1.180} & \multirow[b]{2}{*}{10} \\
\hline & $\%$ & 20.2 & 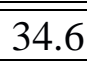 & 24.4 & 12.8 & 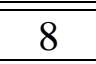 & & & \\
\hline \multirow{2}{*}{$\begin{array}{c}\text { Museum has } \\
\text { updated website } \\
\text { with all information } \\
\end{array}$} & Freq. & 69 & 105 & 189 & 87 & 50 & & & \\
\hline & $\%$ & 13.8 & 21 & 37.8 & 17.4 & 10 & 2.89 & 1.152 & 6 \\
\hline Museum organizes & Freq. & 63 & 118 & 119 & 142 & 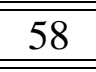 & & & \\
\hline $\begin{array}{l}\text { attracting the } \\
\text { visitors }\end{array}$ & $\%$ & 12.6 & 23.6 & 23.8 & 28.4 & 11.6 & 3.03 & 1.221 & 3 \\
\hline
\end{tabular}




\begin{tabular}{|c|c|c|c|c|c|c|c|c|c|}
\hline \multirow{2}{*}{$\begin{array}{c}\text { Museum offers } \\
\text { online ticket } \\
\text { booking }\end{array}$} & Freq. & 112 & 121 & 112 & 103 & 52 & \multirow{2}{*}{2.72} & \multirow{2}{*}{1.299} & \multirow{2}{*}{8} \\
\hline & $\%$ & 22.4 & 24.2 & 22.4 & 20.6 & 10.4 & & & \\
\hline \multirow{2}{*}{$\begin{array}{l}\text { Museum uses } \\
\text { creative means for } \\
\text { marketing its } \\
\text { activities. }\end{array}$} & Freq. & 54 & 143 & 132 & 132 & 39 & \multirow[b]{2}{*}{2.92} & \multirow[b]{2}{*}{1.136} & \multirow[b]{2}{*}{5} \\
\hline & $\%$ & 10.8 & 28.6 & 26.4 & 26.4 & 7.8 & & & \\
\hline \multicolumn{7}{|c|}{ Average Mean } & 2.91 & 1.200 & - \\
\hline
\end{tabular}

Results in table (11) illustrated that the responses of research sample agree with one statements of Complementary Services dimension according to the mean that has the highest level of agreement which is the accessibility of museum for elderly and disabled visitors by (mean= $3.54 \& \mathrm{SD}=$ 1.07).Meanwhile the answers were neutral on providing cultural hub for workshops, art galleries and cultural salons at the museum by (mean= 3.14), then the statement that is related to organizing regular events for attracting the visitors by (mean= 3.03), followed by the statement of "Museum has entertainment areas such as gardens, movie theatre....etc by (mean= 2.93). Finally the statement of the usage of creative means for marketing the museum's activities) by (mean=2.93). The average mean of all the statements of Complementary Services dimension were towards neutral by $($ mean $=2.91)$.

FOURTH: SATISFACTION LEVEL

Table (12): Respondents' answers on Satisfaction Level

\begin{tabular}{|c|c|c|c|c|c|c|c|c|}
\hline \multirow{2}{*}{\multicolumn{2}{|c|}{ Statements }} & \multicolumn{5}{|c|}{ 5-Point Likert - Scale } & \multicolumn{2}{|c|}{ Statistics } \\
\hline & & 1 & 2 & 3 & 4 & 5 & $\overline{\overline{\mathbf{x}}}$ & SD \\
\hline \multirow{2}{*}{$\begin{array}{l}\text { How can you } \\
\text { evaluate in } \\
\text { general your } \\
\text { visit to the } \\
\text { museum }\end{array}$} & Freq. & 15 & 33 & 109 & 226 & 117 & \multirow{3}{*}{3.79} & \multirow{3}{*}{.972} \\
\hline & $\%$ & 3 & 6.6 & 21.8 & 45.2 & 23.4 & & \\
\hline \multicolumn{7}{|c|}{ Average Mean } & & \\
\hline
\end{tabular}

The results in table (12) showed that the answers of respondents were agree with the statement of satisfaction level dimension according to the mean with the highest level of satisfaction by (mean $=3.79 \& \mathrm{SD}=0.97)$. 


\section{CORRELATIONS AMONG STUDY VARIABLES}

Research relationships among research variables are important to identify the degree of effectiveness for each factor on the other factors.

To test the correlations among research variables, the researcher chooses correlation analysis $(\mathrm{R})$, the coefficient of determination (R Square).

Table (13): Correlation Coefficient between service quality dimensions and satisfaction

\begin{tabular}{|c|c|c|}
\hline \multicolumn{2}{|c|}{ (Independent variables) } & $\begin{array}{l}\text { Dependent variable } \\
\text { (Satisfaction) }\end{array}$ \\
\hline Tangibility & \multirow{5}{*}{ Correlation } & 0.455 \\
\hline Reliability & & 0.251 \\
\hline Responsiveness & & 0.575 \\
\hline Assurance & & 0.758 \\
\hline Empathy & & 0.170 \\
\hline
\end{tabular}

* = Highly significant at $\mathrm{P} \leq 0.05$

From the results in the previous table (13), there is a positive correlation among tangibility, Reliability, Responsiveness, Assurance and Empathy with Satisfaction; when the correlation coefficient of spearman is respectively $0.455,0.251,0.575,0.758,0.170$, thus it is a positive correlation. Thus, the hypotheses H.1, H.2, H.3, H.4, and H.5 could be accepted.

\section{REGRESSION LEVEL}

To determine the effect, the researchers use the simple regression index, which is a measure for the quality of relationships between two variables in the form of a significant relationship.

Table (13): The Simple Regression

\begin{tabular}{|c|c|c|c|c||}
\hline Variables & $\mathbf{R}$ & $\begin{array}{c}\mathbf{R} \\
\text { Square }\end{array}$ & $\begin{array}{c}\text { Adjusted } \\
\text { R Square }\end{array}$ & $\begin{array}{c}\text { Std. Error of } \\
\text { the Estimate }\end{array}$ \\
\hline \hline Tangibility and Satisfaction & 0.462 & 0.213 & 0.211 & 0.475 \\
\hline \hline $\begin{array}{c}\text { Reliability and } \\
\text { Satisfaction }\end{array}$ & 0.291 & 0.083 & 0.085 & 1.211 \\
\hline \hline $\begin{array}{c}\text { Responsiveness and } \\
\text { Satisfaction }\end{array}$ & 0.58 & 0.255 & 0.330 & 0.412 \\
\hline \hline Assurance and Satisfaction & 0.76 & 0.349 & 0.686 & 0.732 \\
\hline \hline Empathy and Satisfaction & $.170^{\mathrm{a}}$ & 0.029 & 0.025 & 0.593 \\
\hline
\end{tabular}


From table (13), R Square has a value of 0.213 while the Adjusted R Square was 0.211 , which indicates a decrease in the difference between them at a standard error of 0.475 , as it emphasizes the quality and accuracy of the results, and accordingly the independent variable is (Tangibility) explains $2.1 \%$ of the changes in the dependent variable, which is (Satisfaction) Moreover, R Square has a value of 0.083 while the Adjusted $\mathrm{R}$ Square was 0.085 which indicates increase in the difference between them at a standard error of 1.211, as it emphasizes the quality and accuracy of the results, and accordingly the independent variable is (Reliability) explains $0.8 \%$ of the changes in the dependent variable, which is (Satisfaction). Here, R Square has a value of 0.255 while the Adjusted R Square was 0.330, which indicates increase in the difference between them at a standard error of 0.412 , as it emphasizes the quality and accuracy of the results, and accordingly the independent variable is (Responsiveness) explains $2.5 \%$ of the changes in the dependent variable, which is (Satisfaction). The R Square has a value of 0.349 while the Adjusted $\mathrm{R}$ Square was 0.686 , which indicates increase in the difference between them at a standard error of 0.732 , as it emphasizes the quality and accuracy of the results, and accordingly the independent variable which is (Assurance) explains $3.4 \%$ of the changes in the dependent variable, which is (Satisfaction). Finally, R Square has a value of 0.029 while the Adjusted R Square was 0.025 , which indicates increase in the difference between them at a standard error of 0.59 , as it emphasizes the quality and accuracy of the results, and accordingly the independent variable which is (Empathy) explains $0.2 \%$ of the changes in the dependent variable, which is (Satisfaction).

\section{CONCLUSION}

By assessing the dimensions that influence the service quality in museums, it was found that the presence of professional and knowledgeable tour guide who can explain the exhibits is the main element that affects greatly visitors' satisfaction level towards the visit.

There is a positive correlation between the five dimensions of service quality and the satisfaction, that the more tangibility, reliability, responsiveness, assurance and empathy, the more satisfaction of the visitor.

It was found that there is a positive significant relationship between the quality dimensions and satisfaction as follows: assurance, responsiveness, tangibility, reliability, and then finally empathy.

On the other hand, Luxor Museum is the highest visited museum at Upper Egypt region followed by the Nubian Museum, and the repetition of the 
visits indicates that the satisfaction affects visitors' desire to revisit the museum once again.

Regarding the visual appealing and the tangibility dimension, it is noticed that the highest agreement regarding the museum is the cleanness of it and the adequacy distance between exhibits and visitors. Meanwhile, the highest agreement regarding the exhibits shown is that they have artistic value and they are related to the region to which the museum belongs to. For the displayed cabinets, it is agreed that the size of exhibits inside them ensure their safety.

\section{RECOMMENDATIONS}

1. Tour Guides Syndicate must stress more training courses for tour guides to ensure their quality in providing distinctive and knowledgeable information to museums' visitors.

2. Ministry of Tourism and Antiques has to make a tight control on the cleanness of the museums (inside and outside) in addition to adding pieces related to the region in which the museum belongs to, for the reason of adding value to it. It has to cooperate with the Ministry of Tourism and Tourism Promotion Authority in marketing and promoting all Upper Egypt museums to increase their market share of visits. It also has to establish well equipped bazars, cafes and restaurants attached to museums to let visitors buy various souvenirs through bazars for distinguishing their visit and also providing food and beverage through cafes and restaurants.

3. Museums have to cooperate with Ministry of Tourism and Antiques to organize cultural hubs for workshops, art galleries and cultural salons in addition to regular events to attract museums' visitors.

4. The regional museums must be included in visiting programs.

\section{REFERENCES}

Ali, H. Y., Ali, H. F., and Ahmad, M. B. (2019). Difference between Expectations and Perceptions of Students Regarding Service Quality of Public Sector HEIs. Bulletin of Education and Research, 41(1), 131-146.

Barshan, G., Elahi, A., and Aghaei, N. (2017). Impact of service quality on satisfaction, loyalty and intention to revisit of sport customers: The case study of swimming pools in Alborz Province. International Review of Management and Marketing, 7(2), 334-339. 
Bhat, M. (2012). Tourism Service Quality: A Dimension-specific Assessment of SERVQUAL, Global Business Review, 13(2), SAGE Publications, London, 327-337.

Castellani, P.; Conti, E., Rossato, C. and Vesci, M (2019). Applying the "SERVICESCAPE THEORY" to the Museums: First Evidence from Italy, Excellence in Services, $22^{\text {nd }}$ International Conference, Greece, 97- 109.

Daskalaki,V.; Voutsa, M. Boutsouki, C. and Hatzithomas, L.(2020). Service Quality, Visitor Satisfaction and Future Behavior in the Museum Sector, Journal of Tourism, Heritage \& Services Marketing, 2020, Vol. 6, No. 1, 3-8.

Duantrakoonsil, T.; Reid, E. and Lee, H. (2017). Museum Service Quality, Satisfaction, and Revisit Intention: Evidence from the Foreign Tourists at Bangkok National Museums in Thailand, Culinary Science \& Hospitality Research 23(6), 127-134.

El Mallah, M. Y. (2018). The Luxor Museum of Ancient Egyptian Art: The Challenge of Abundance, Museum International Journal, Vol, 50, Issue 2, 16- 22

El Saghier, N. (2015). Managing Service Quality: Dimensions of Service Quality: a Study in Egypt, International Journal of African and Asian Studies, Vol.9, 56-63.

Elcheikh, Z. (2014). Outside the Walls of the Nubian Museum. Annual Digital Journal on Research in Conservation and Cultural Heritage, 4, 32- 33.

Findlen, P. (1989). The Museum: Its Classical Etymology and Renaissance Genealogy, Journal of the History of Collections, 1 (1), 59-78.

Frochot, I and Hughes, H., (2000). HISTOQUAL: The development of historic houses assessment scale, Tourism Management (21) 157167.

Gebremichael, G. and Singh, A., (2019). Customers' Expectations and Perceptions of Service Quality Dimensions: A Study of The Hotel Industry in Selected Cities of Tigray Region, Ethiopia, African Journal of Hospitality, Tourism and Leisure, Vol 8 (5), 1-15.

Goetsch, D. and Davis, S. (2014). Quality Management for Organizational Excellence, Introduction to Total Quality, Ninth Edition, Pearson Education, Inc., United States of America.

Hawass, Z. and Kamrin, J. (2010). The Illustrated Guide to the Luxor Museum of Ancient Art and the Nubia Museum of Aswan: With the Luxor Mummification Museum and the Kom Ombo Crocodile Museum, American Univ. in Cairo Press, 15.

Hawass, Z. (2005). A New Era for Museums in Egypt, Museum International Journal, 57(1-2), 7. 
Hui-Ying, S. and Chao-Chien, C. (2008). A Study of Service Quality and Satisfaction for Museums - Taking the National Museum of Prehistory as an Example, The Journal of Human Resource and Adult Learning Vol. 4, No 1, 159- 170.

Kabir, H. and Carlsson, T. (2010). Service Quality - Expectations, Perceptions and Satisfaction about Service Quality at Destination Gotland - A case study, Master thesis in Business Administration, Gotland University, 1-51.

KS, K. and Thomas, B. (2015). Customer Expectations and Perceptions of Service Quality of Mobile Phone Service Providers in Kerala- A Gap Analysis, Interational Journal of Management (IJM), Vol 6, Issue 3, 50-65.

Marković, S.; Raspor, J., and Sanja (2019). Assessing the Service Quality and Customer Satisfaction Relationship in the Croatian Museum Sector, Modern Management Tools and Economy of Tourism Sector in Present Era, Association of Economists and Managers of the Balkans, Beograd, 223-234.

Marković,S.; Raspor, S. and Komšić, J. (2013). Museum Service Quality Measurement Using the HISTOQUAL MODEL, Tourism in Southern and Eastern Europe, 201-216.

Mey, L. and Mohamed, B. (2010). Service Quality, Visitor Satisfaction and Behavioral Intentions: Pilot Study at a Museum in Malaysia, Journal of Global Business and Economics, Vol. 1, No 1, 226-240.

Ministry of Tourism and Antiques (2021). Mummification Museum: https://egymonuments.gov.eg/museums/mummification-museum/ Accessed 29-7- 2021.

Nowacki, M. (2005). Evaluating a Museum as a Tourist Product Using the SERVQUAL method, Museum Management and Curatorship (20), 235-250.

Omar, M., Ariffin, H. and Ahmad, R. (2016). Service Quality, Customers' Satisfaction and the Moderating Effects of Gender: A Study of Arabic Restaurants, Procedia - Social and Behavioral Sciences 224, $384-392$.

Pakurár, M.; Haddad, H.; Nagy, J. f.; Popp, J., and Oláh, J. (2019). The Service Quality Dimensions that Affect Customer Satisfaction in the Jordanian Banking Sector, MDPI Sustainability journal, Basel, Switzerland.

Paolini, A. (2005). Successes and Outcomes of the Nubia Campaign, Museum International Journal, 57 (1-2), 56.

Parasuraman, A., Berry, L. L. and Zeithaml, V.A. (1985). A Conceptual Model of Service Quality and its Implications for Future Research, Journal of Marketing, Vol 49, 41- 50. 
Parasuraman, A ., Berry, L. L. and Zeithaml, V.A. (1988). SERVQUAL: A Multiple-item Scale for Measuring Consumer Perceptions of Service Quality, Journal of Retailing, Vol 64, No.1, 14- 40.

Phaswana- Mafuya, N. and Haydam, N. (2005). Tourists' Expectations and Perceptions of the Robben Island Museum- A World Heritage Site, Museum Management and Curatorship (20), 149-169.

Preko, A.; Gyepi-Garbrah, T.; Arkorful, H.; Akolaa, A. and Quansah, F. (2020). Museum experience and satisfaction: moderating role of visiting frequency, International Hospitality Review, Vol. 34, No. 2, 203-220.

Pwelle, E. (2014). Assessment of Service Quality in Tanzania's Museums and its Effects on Customer Satisfaction: A Case Study of Mkwawa Memorial Museum in Iringa, Tanzania, Master Degree of Buisness Administration (MBA), Open University of Tanzania.

Qadri, U. (2015). Measuring Service Quality Expectation and Perception Using SERVQUAL: A Gap Analysis, Business and Economics Journal, Vol 6 , Issue 3, 1-6.

Radder, L. and Han, X. (2011). Measurement and Consequences of U.S. Touristse Perceptions of Service Quality: A South African Hunting Safari Case Study, International Business \& Economics Research Journal, Vol 10, Number 5, 33-48.

Ramya, N.; Kowsalya, A. and Dharanipriya, K. (2019). Service Quality and Its Dimensions, EPRA, International Journal of Research and Development (IJRD), Vol. 4, Issue: 2, 38-41.

Rentschler, R. and Gilmore, A. (2002). Museums: Discovering Services Marketing, International journal of Arts Management, Vol. 5, no. 1, Fall, 62-72.

Seetue, P. (2009). An investigation on visitor's satisfaction based on service quality dimensions at the national Discovery Museum Institute: A case study of the museum of Siam, Bangkok, Thailand, Master of business administration thesis, Assumption University, Bangkok, Thailand.

Taber, K. (2018). The Use of Cronbach's Alpha When Developing and Reporting Research Instruments in Science Education. Research in Science Education, 48: 1273-1296.

Țîțu, M., Răuleaa, A. and Țîțu, S. (2016). Measuring Service Quality in Tourism Industry, Procedia- Social and Behavioral Sciences 221, 294-301.

Ünuvar, S.; Yapici, O. and Ozisik, O. (2016). A Study on The Measurement of Service Quality in Museums Using The HISTOQUAL Model: Case of Samsun,,$I^{\text {st }}$ International Academic Research Congress, 3-5 November, 1440-1449, Pegem Akademi, Ankara. 